UDC 574.24: 57.045: 550.386 .6

DOI: $10.21668 /$ health.risk/2021.3.13.eng

Research article

\title{
GEOMAGNETIC CHANGES AS A RISK FACTOR CAUSING OXIDATIVE STRESS IN HUMAN ERYTHROCYTES
}

\author{
A.M. Irkaeva ${ }^{1,2}$, E.S. Zhukova ${ }^{1}$, T.G. Shcherbatyuk ${ }^{1,3,4}$, V.V. Chernov', \\ L.V. Polyakova ${ }^{1,2}$, M.A. Pozdnyakova ${ }^{1}$, I.A. Umnyagina ${ }^{1}$
}

${ }^{1}$ Nizhny Novgorod Scientific Research Institute for Hygiene and Occupational Pathology, 20 Semashko Str., Nizhny Novgorod, 603005, Russian Federation

${ }^{2}$ Lobachevsky State University of Nizhny Novgorod, 23 Gagarin Ave, Nizhny Novgorod, 603022, Russian Federation ${ }^{3}$ Moscow Region State University, 24 Very Voloshinoy Str., Mytishi, 141014, Russian Federation

${ }^{4}$ Pushchino State Institute of Natural Science, 3 Nauki Ave., Pushchino, 142290, Russian Federation

${ }^{5}$ Institute of Applied Physics of the Russian Academy of Sciences, 46 Ul'yanov Str., Nizhny Novgorod, 603950, Russian Federation

At present impacts exerted by heliogeophysic factors on different living organisms are being examined more and more intensely. Over the last decade, it has been detected that meteorological factors play an important role in formation of adaptation mechanisms in living systems. Sun and earth interaction is also known to directly influence rheological properties of human blood, both in a healthy body and in case there are chronic non-communicable diseases. Given that, impacts exerted by "cosmic weather" on living organisms, people in particular, are a stimulus to perform profound studies on reactions occurring as a response to effects produced by solar and geomagnetic activity, first of all, solar flares and magnetic storms.

At present the most widely used approach to determining influences exerted by the Earth magnetic field on biological systems involves searching for correlations between different parameters of living organisms functioning and geomagnetic indexes.

Our research goal was to assess dependence between enzymatic activity of antioxidant protection system, exemplified by superoxide dismutase (SOD) and catalase, and geomagnetic field disturbances.

The research focused on examining blood samples taken from conditionally healthy volunteers living in Nizhny Novgorod region. SOD and catalase activity were determined in blood erythrocytes with spectrophotometry. Geomagnetic disturbances force was determined as per planetary Kp-index value.

The research established a statistically significant correlation between SOD and catalase activity and a value of geomagnetic field disturbance; this correlation allows making an indirect assumption that geomagnetic conditions directly influence superoxide radical production in a body.

Therefore, a change in superoxide radical production is a way for the geomagnetic field to influence living organisms. Activation of free radical oxidation can make for both occurrence and more intense clinical course of several diseases (especially cardiovascular and neuropsychic ones). So, in future it is advisable to assess reactivity of antioxidant protection system as a response to geomagnetic fluctuations in case there are pathologic changes in a body.

Key words: geomagnetic disturbances, solar activity, heliobiology, Kp-index, superoxide dismutase, catalase, magnetic sensitivity, human body.

(C) Irkaeva A.M., Zhukova E.S., Shcherbatyuk T.G., Chernov V.V., Polyakova L.V., Pozdnyakova M.A., Umnyagina I.A., 2021

Anastasiya M. Irkaeva - laboratory assistant-researcher; 1st year postgraduate student (e-mail: irkaeva-anastasiya@, inbox.ru; tel.: +7 (831) 436-00-52; ORCID: https://orcid.org/0000-0002-4509-2151).

Evgeniya S. Zhukova - Researcher, Head of laboratory (e-mail: evgenya_plekhanova@mail.ru; tel.: +7 (831) 436-00-52; ORCID: https://orcid.org/0000-0002-9016-2390).

Tatiana G. Shcherbatyuk - Doctor of Biological Sciences, Professor; Professor at Pushchino State Institute for Natural Sciences, Chief Researcher at Moscow State Regional University, Chief Researcher at Nizhny Novgorod Research Institute for Hygiene and Occupational Pathology (e-mail: ozone_stg@mail.ru; tel.: +7 (831) 436-00-52; ORCID: https://orcid.org/0000-0003-1144-8006).

Vladimir V. Chernov - Candidate of Physical and Mathematical Sciences, Senior researcher at the Applied Physics Institute of the Russian Academy of Sciences (e-mail: vcher@appl.sci-nnov.ru; tel.: +7 (831) 436-00-52; ORCID: https://orcid.org/0000-0002-0871-5954).

Lyubov V. Polyakova - laboratory assistant-researcher; 1st year postgraduate student (e-mail: polaykova2016@mail.ru; tel.: +7 (831) 436-00-52; ORCID: https://orcid.org/0000-0002-7056-734X).

Marina A. Pozdnyakova - Doctor of Medical Sciences, Professor; a member of the Association for Hygienic Organizations and Experts "Hygienists Union", Chief Researcher, Head of the Department for Medical and Preventive Technologies for Public Health Risk Management, Head of the Center for Postgraduate Professional Medical Education of Nizhny Novgorod Scientific Research Institute for Hygiene and Occupational Pathology (e-mail: prof_pozdniakova@mail.ru; tel.: +7 (831) 436-00-52; ORCID: https://orcid.org/0000-0002-7767-6098).

Irina A. Umnyagina - Candidate of Medical Sciences, Director (e-mail: recept@nniigp.ru; tel.: +7 (831) 419-61-94; ORCID: https://orcid.org/0000-0002-9276-7043). 
At present, sufficient data have been accumulated on influence exerted by space factors on the biosphere but their action mechanisms have not been studied enough [1-8]. Such ecological impacts have apparent biotropic effects that result in biochemical and physiological transformations in living organisms [9] and become obvious not only through changes in individual development cycle but also through effects produced on development of next generations as a whole [10]. Better insight into these fundamental mechanisms is a necessary basis of predictive and preventive programs in medicine.

The Sun is known to be the primary source of space weather on the Earth since this star is the closest to our planet. Influence by the Sun occurs due to electromagnetic radiation in various ranges, stellar wind flows, solar cosmic rays, solar flares and corona mass ejections. The Earth has its own shield to protect from destructive effects produced by these phenomena; this shield is the planetary magnetic field and the ozone layer in the atmosphere. However, some highspeed charged particles can penetrate into the Earth magnetosphere thus leading to changes in the atmosphere and ionosphere. Quantity and intensity of influencing solar factors grows as the star becomes more active, and rises in solar activity repeat periodically at the beginning of each new cycle which is conditionally called "11-year one" [11]. According to official data provided by the Space Weather Prediction Center, the USA, the $24^{\text {th }}$ solar cycle ended relatively not long ago (minimal activity was registered in December 2019), and then the $25^{\text {th }}$ cycle started with maximum activity predicted in between November 2024 and March 2026. More intense radiation at various frequencies and corpuscular fluxes lead to ellipticity of magnetosphere and an increase in the geomagnetic field intensity. Thus a geomagnetic storm is born as global disturbance in the Earth magnetosphere [12].

We should keep in mind that there is a certain time gap between occurring heliogeo- physical disturbances and such responses to them as changes in physiological state of the body. These responses occur in most people at the beginning of global disturbance in the Earth magnetosphere, 2-3 days after a solar flare. However, some people become sensitive even 1-2 days prior to a geomagnetic storm arises. This effect is partially due to solar influence being multi-component and these components moving at different speed: electromagnetic radiation in any range covers the distance from the Sun to the Earth in 8-10 minutes while it takes corpuscular fluxes 2430 hours to reach the planet [13].

It should be noted that influence exerted by solar activity on processes in the living nature at all levels of biological systems organization, including human health and population morbidity and even social and historical events, was established as far back as in 20ties last century by A.L. Chizhevsky, an outstanding Soviet scientist and the founder of contemporary heliobiology. Since then, multiple facts have been accumulated on impacts exerted by fluctuations in physical fields in the Near-Earth space that disrupt functioning of various physiological systems in the human body $[12,14]$. According to upto-date concepts, the cardiovascular system and the nervous system are the most sensitive to changes in space weather and the fact is confirmed by observed rises in morbidity and mortality among patients with pathologies of these systems during disturbances in the magnetosphere [15-19].

Moreover, it was established that healthy people had different blood system parameters during years with maximum and minimum solar activity [20-21]. When it comes down to practical medicine, it is important to keep in mind influence exerted on the body not only by fluctuations in the solar activity that are averaged over a long period of time but also individual ones such as flares and falls in separate days. We should note that such changes in the solar activity result in abnormal strengthening of solar wind that creates geomagnetic storms. Geomagnetic field fluc- 
tuations may become health risk factors since they make for disorders in coordination between rhythms of biological processes in living organisms and environmental cycle recurrence [22].

We can also mention that intense magnetic disturbances sometimes occur due to unknown reasons; in this case it is difficult to detected a source of these fluctuations since there are no active events on the Sun that are directed at the Earth. A magnetic storm of G3 level registered on May 12, 2021 that was the greatest since 2019 can be a good example. According to data provided by the laboratory of X-ray Astronomy of the Sun at the Institute of Physics, the Russian Academy of Sciences [23], geomagnetic disturbance intensity reached $\mathrm{Kp}$-index value equal to 7 as per a 9 -score scale at the peak of the storm that occurred in the evening, between 3 and 9 pm Moscow time. Actually it was just one but very powerful space strike on the Earth. Solar flares that were registered during those days occurred on such spots on the Sun that were remote from direction at the Earth and the storm was not predicted at all.

It is noted that various molecules, for example, paramagnetic free radicals, can serve as "receiving elements for an external magnetic signal. Paramagnetic properties of these reaction-active particles are determined by an unpaired electron on the external valent layer and this makes them unstable. These very molecules are intermediate participants in such biochemical reaction as one-electron reduction. Therefore, geomagnetic variations follow this mechanism to manage free radical processes of substance transformation." [24].

Various physical indicators (Kp-, Ap-, $\mathrm{C}$-index and some others) are applied to determine geomagnetic activity. Kp-index is the most widely used one; it measures geomagnetic field fluctuations. This indicator shows a deviation in the Earth magnetic field from its normal state during a 3-hour interval. Its values vary from 0 to 9 and are calculated as an average for values provided by several geomagnetic observatories located between 44 and 60 degrees of northern and southern latitudes. Geomagnetic storms are relatively short (from 6-7 hours to several days) and after their end physical parameters of the geomagnetic field return to their initial values. G-index characterizes intensity of variations in a geomagnetic storm as per a 5-score scale with storm gradation starting from G1 (weak storm) to G5 (extremely strong storm) $[25,26]$.

At present, mechanisms of influence exerted by geomagnetic field disturbances on biological systems, people included, have not been studied enough. Search for magnetosensitive markers can be a promising approach to revealing mechanisms of such influence [27].

Our research goal was to assess dependence between enzymatic activity of antioxidant protection system and geomagnetic field disturbances.

Materials and methods. We examined blood samples taken from conditionally healthy volunteers who lived in Nizhny Novgorod region $(n=37)$. Biological materials were taken from September 2019 to February 2020, in the morning hours from 8 am to 9 am. Donors' age varied from 19 to 58 years. To assess influence exerted by geomagnetic situation on antioxidant protection system, we focused on superoxide dismutase (SOD) and catalase since these enzymes belong to the first section in intracellular protection from reactive oxygen species. SOD activity was determined as per inhibition of recovery rate detected for nitroblue tetrazolium in nonenzymatic system of phenazine methosulfate and nicotinamide adenine dinucleotide $(\mathrm{NADN})^{1}$. Catalase activity was determined by spectrophotometry in erythrocytes as per

\footnotetext{
${ }^{1}$ Arutyunan A.V., Dubinina E.E., Zybina N.N. Metody otsenki svobodnoradikal'nogo okisleniya i antioksidantnoi sistemy organizma [Procedures for estimating free radical oxidation and antioxidant system in the body]. Saint Petersburg: IKF "Foliant", 2000, 104 p. (in Russian).
} 
changes in optical density in a region of hydrogen peroxide absorption [28]. Intensity of geomagnetic disturbances was estimated as per planet Kp-index; its values for Nizhny Novgorod region on a day when biological materials were taken were available at www.tesis.lebedev.ru [23]. It is the official web-site of the laboratory of X-ray Astronomy of the Sun at the Institute of Physics, the Russian Academy of Sciences where uninterrupted monitoring over the conditions of the Sun is conducted. Correlations between data were estimated with correlation analysis according to Spearman.

Results and discussion. The research revealed a statistically significant correlation between activity of anti-oxidant enzymes in erythrocytes and planet Kp-index (Figures 1 and 2).

On days when Kp-index values were high, SOD and catalase enzymes became more active in erythrocytes of healthy volunteers. Superoxide dismutase turned out to be more sensitive to geomagnetic situation since we detected statistically significant positive correlations between its activity and planet $\mathrm{Kp}$ index values, both 2.5-3.0 hours prior to blood sampling (Figure 1A) and values at the moment blood was being sampled (Figure 1B), as well as average planet $\mathrm{Kp}$-index values over the whole day of blood sampling (Figure 1C). Correlation between catalase activity and $\mathrm{Kp}$ index values was detected only for $\mathrm{Kp}$-index values 2.5-3.0 hours prior to blood sampling (Figure 2).

SOD and catalase are known to be highspecialized antioxidant enzymes. Superoxide dismutase serves as a catalyst in a reaction of superoxide dismutation into hydrogen peroxide and oxygen. Catalase participates in hydrogen peroxide decomposition thus preventing formation of hydroxyl radicals when hydrogen peroxide interacts with iron or copper ions as per the Fenton reaction [29].

Detected correlations between geomagnetic activity and activity of the analyzed enzymes can give grounds for an implicit assumption that geomagnetic situation has direct influence on production of superoxide radical; and, as it is well known, non-enzymatic

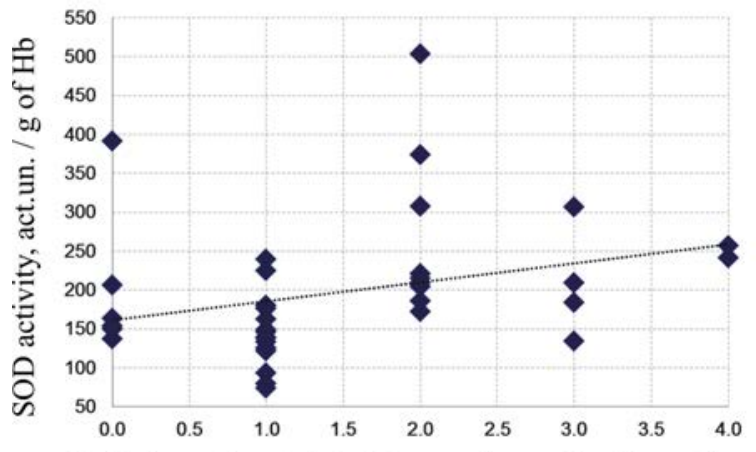

$\mathrm{Kp}$-index values $2.5-3.0$ hours prior to blood sampling A

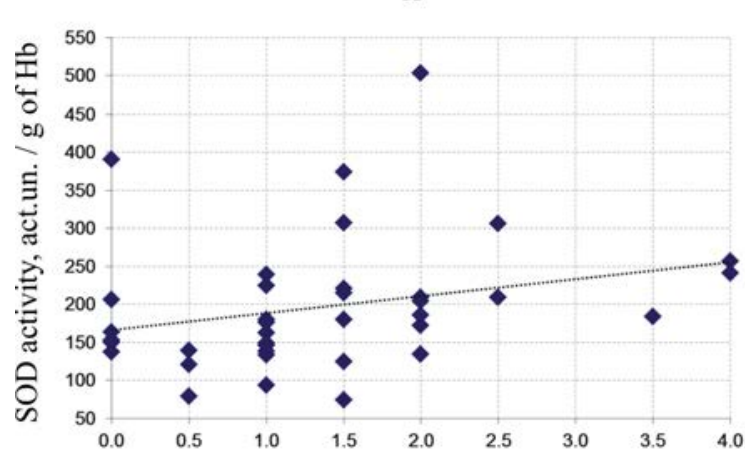

$\mathrm{Kp}$-index values at the moment blood was being sampled

B

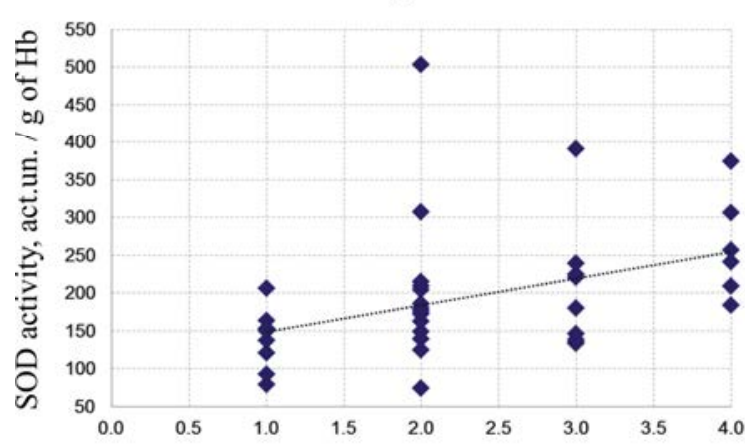

Averaged $\mathrm{Kp}$-index values on a day of blood sampling

C

Figure 1. Correlaiton field for dependence between antioxidant enzyme superoxide dismutase and geomagnetic situation: $\mathbf{A}, 2.5-3.0$ hours prior to blood sampling (Spearman's correlation $r=0.44$, $p=0.007) ; \mathbf{B}$, at the moment blood was being sampled (Spearman's correlation $r=0.37$, $p=0.013) ; \mathbf{C}$, average value on a day of blood sampling (Spearman's correlation $r=0.50$,

$$
p=0.002 \text { ) }
$$

spontaneous hemoglobin oxidation into methemoglobin is a basic source of superoxide anion in erythrocytes (Figure 3). It is in line with the concept by V.P. Reutov [1] according to which $\mathrm{Fe}^{2+}$-containing proteins are targets for effects 


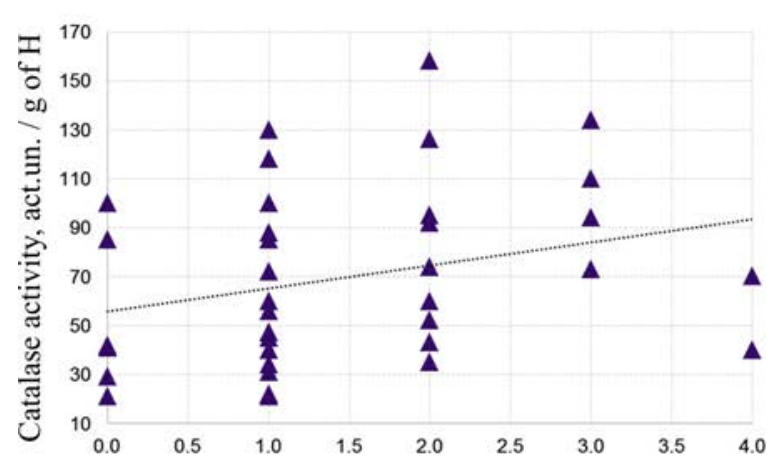

Kp-index values $2.5-3.0$ hours prior to blood sampling

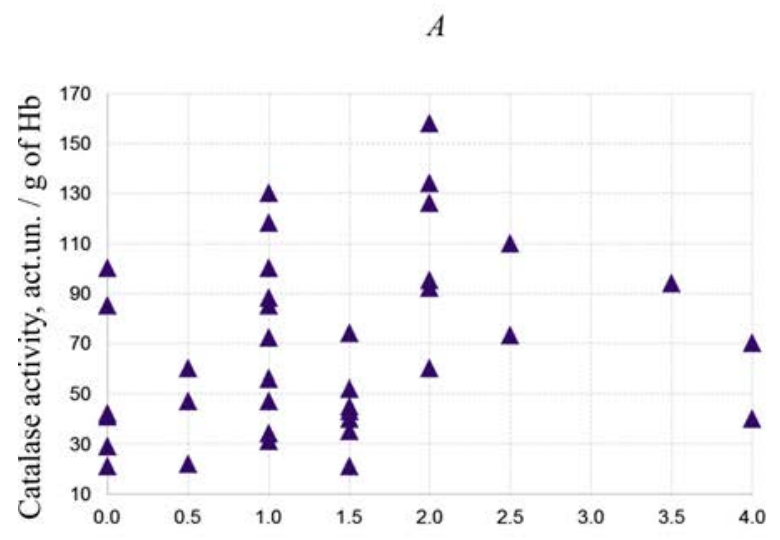

$\mathrm{Kp}$-index values at the moment blood was being sampled

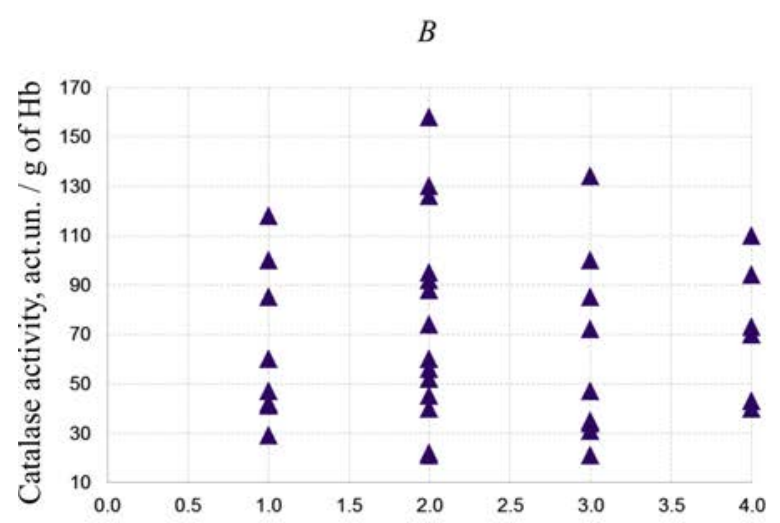

Average $\mathrm{Kp}$-index values on a day of blood sampling

C

Figure 2. Correlaiton field for dependence between antioxidant enzyme catalase and geomagnetic situation: A, 2.5-3.0 hours prior to blood sampling (Spearman's correlation $r=0.34, p=0.041$ ); $\mathbf{B}$, at the moment blood was being sampled (Spearman's correlation $r=0.32, p>0.05$ ); $\mathbf{C}$, average value on a day of blood sampling (Spearman's correlation $r=-0.01, p>0.05$ )

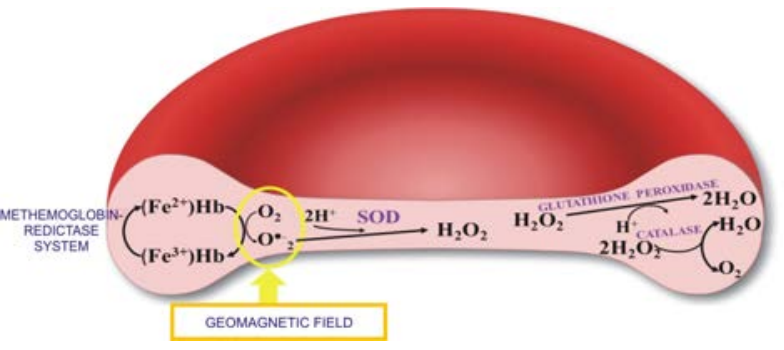

Figure 3. Scheme showing generation and neutralization of superoxide radical and hydrogen peroxide in erythrocytes

produced by geomagnetic field. The fact that the detected correlation is moderate is probably due to, first of all, absence of strong geomagnetic storms during the observation period, and, secondly, individual peculiarities of participating volunteers.

The detected correlation between catalase activity and geomagnetic situation several hours prior to blood sampling might be weak due to absence of any direct effects produced by the Earth magnetic field on generation of hydrogen peroxide $\mathrm{H}_{2} \mathrm{O}_{2}$ in erythrocytes. Instead, we can see only indirect influence through dismutation reaction catalyzed by SOD that results in hydrogen peroxide formation and catalase activity changes accordingly (Figure 3).

Conclusion. Therefore, there is indirect evidence that a change in production of superoxide radical is a mechanism of influence exerted by the geomagnetic filed on living organisms. Activation of free radical oxidation can make for development and aggravation of many diseases (especially cardiovascular and neuropsychic ones). Therefore it seems advisable to estimate responses by antioxidant protection system to geomagnetic fluctuations in case there are pathological changes in the body.

Funding. The research was not granted any sponsor support.

Conflict of interests. The authors declare there is no any conflict of interests. 


\section{References}

1. Reutov V.P. Na puti k sozdaniyu teorii vliyaniya kosmicheskoi pogody na organizm cheloveka: novaya kontseptsiya. Misheni dlya gelio- i geomagnitnykh variatsii: vozmozhnaya rol' Fe2+-soderzhashchikh belkov i SH-soderzhashchikh nizkomolekulyarnykh soedinenii i belkov / fermentov, uchastvuyushchikh v protsessakh dykhaniya, obrazovanii ATF i tsiklicheskikh prevrashcheniyakh gazotransmitterov [On the way to creating a theory on influence exerted by cosmic weather on a human body: a new concept. Targets for helio- and geomagnetic variations: a probable role by $\mathrm{Fe}^{2+}$-containing proteins and $\mathrm{SH}$-containing low molecular compounds and proteins/enzymes that participate in breathing, ATP formation and cyclic transformations of gas transmitters]. Evraziiskoe Nauchnoe Ob"edinenie, 2017, vol. 1, no. 8 (30), pp. $42-53$ (in Russian).

2. Yakovlev M.Yu., Saltykova A.D., Banchenko A.D., Fedichkina T.P., Nagornev S.N., Khudov V.V., Balakaeva A.V., Bobrovnitskii I.P. Basic mechanisms corresponding development of meteotropic reactions and use of climate procedures of preventive direction. Mezhdunarodnyi zhurnal prikladnykh i fundamental'nykh issledovanii, 2018, no. 10, pp. 187-192 (in Russian).

3. Reutov V.P., Parshina S.S., Samsonov S.N., Sorokina E.G. Kosmicheskaya pogoda: vzaimosvyaz' mezhdu deistviem fizicheskikh i khimicheskikh faktorov na zhivye organizmy [Cosmic weather: a correlation between impacts exerted by physical and chemical factors on living organisms]. Evraziiskoe Nauchnoe Ob"edinenie, 2017, vol. 1, no. 9 (31), pp. 47-58 (in Russian).

4. Alabdulgader A., McCraty R., Atkinson M., Dobyns Y., Vainoras A., Ragulskis M., Stolc V. Long-Term Study of Heart Rate Variability Responses to Changes in the Solar and Geomagnetic Environment. Scientific reports, 2018, vol. 8, no. 1, pp. 2663. DOI: 10.1038/s41598-018-20932-x

5. Palmer S.J., Rycroft M.J., Cermack M. Solar and geomagnetic activity, extremely low frequency magnetic and electric fields and human health at the Earth's surface. Surveys in Geophysics, 2006, no. 27, pp. 557-595. DOI: 10.1007/s10712-006-9010-7

6. Zaslavskaya R., Shcherban' E., Teiblyum M. Impact of meteorological and geomagnetic factors on cardiovascular system. International Independent Scientific Journal, 2021, no. 23-1, pp. 5-15 (in Russian).

7. Soroko S.I. Influence of cosmogeophysical factors on living organisms. Vestnik obrazovaniya i razvitiya nauki Rossiiskoi akademii estestvennykh nauk, 2019, vol. 23, no. 2, pp. 69-81 (in Russian).

8. Zenchenko T.A., Breus T.K. Potential impacts of weather and climate slow variations on human health and wellness. Current perspectives. Geosfernye issledovaniya, 2020, no. 3, pp. 80-96. DOI: $10.17223 / 25421379 / 16 / 7$ (in Russian).

9. Kulakova K.S., Davydenko D.V., Shcherbatyuk T.G., Chernov V.V., Makusheva M.A. Investigation of free-radical processes in rat organisms on the background of environmental changes. Vestnik Nizhegorodskogo universiteta im. N.I. Lobachevskogo, 2010, vol. 4, no. 1, pp. 100-108 (in Russian).

10. Kulikov V.Yu., Utyupina K.Yu., Krasner Ya.A. Influence of magnetic storms on features of psychophysiological status of students. Meditsina i obrazovanie v Sibiri, 2011, no. 3. Available at: https://cyberleninka.ru/article/n/vliyanie-magnitnyh-bur-na-osobennosti-psihofiziologicheskogo-statusa-u-studentov (09.08.2021) (in Russian).

11. Hathaway D.H. The Solar Cycle. Living reviews in solar physics, 2015, vol. 12, no. 4. DOI: 10.1007/lrsp-2015-4

12. Tsandekov P.A. Influence of cosmophysical fluctuations on the man. Samarskii nauchnyi vestnik, 2014, vol. 9, no. 4, pp. 136-138 (in Russian).

13. Nikberg I.I. Vliyanie geomagnitnykh bur' na zdorov'e cheloveka [Effects produced by geomagnetic storms on human health]. Novosti meditsiny i farmatsii, 2014, vol. 488, no. 4, pp. 16-17 (in Russian).

14. Varakin Yu.Ya., Ionova V.G., Sazanova E.A., Sergeenko N.P. Changes of catecholamins and rheological characteristics of human blood under influence of heliogeophysical factors. Ekologiya cheloveka, 2013, no. 7, pp. 27-33. DOI: 10.33396/1728-0869-2013-7-27-33 (in Russian).

15. Varakin Yu.Ya., Ionova V.G., Gornostaeva G.V., Sazanova E.A., Tedoradze R.V. Impact of heliogeophysical disturbances on haemorheological parameters in healthy people. Zemskii vrach, 2011, no. 2, pp. 21-24 (in Russian). 
16. Mattoni M., Ahn S., Fröhlich C., Fröhlich F. Exploring the relationship between geomagnetic activity and human heart rate variability. Eur. J. Appl. Physiol., 2020, vol. 120, no. 6, pp. 1371-1381. DOI: $10.1007 / \mathrm{s} 00421-020-04369-7$

17. Vladimirsky B.M., Temuryants N.A., Tumanyants K.N., Chuyan E.N., Biological objects protection from the space weather variations: possibility of substantiation. Prostranstvo $i$ Vremya, 2017, vol. 28-29-30, no. 2-3-4, pp. 301-308 (in Russian).

18. Vaičiulis V., Venclovienè J., Tamošiūnas A., Kiznys D., Lukšienė D., KrančiukaitèButylkinienė D., Radišauskas R. Associations between Space Weather Events and the Incidence of Acute Myocardial Infarction and Deaths from Ischemic Heart Disease. Atmosphere, 2021, vol. 12, no. 3, pp. 306. DOI: 10.3390/atmos12030306

19. McCraty R., Atkinson M., Stolc V., Alabdulgoder A., Vainoras A., Ragulskis M. Synchronization of human autonomic nervous system rhythms with geomagnetic activity in human subjects. Int. J. Environ. Res. Public Health, 2017, vol. 14, no. 7, pp. 770. DOI: 10.3390/ijerph14070770

20. Gurfinkel Y.I., Ozheredov V.A., Breus T.K., Sasonko M.L. The Effects of Space and Terrestrial Weather Factors on Arterial Stiffness and Endothelial Function in Humans. Biophysics, 2018, vol. 63, no. 2, pp. 299-306. DOI: 10.1134/S0006350918020094

21. Sterlikova I.V. Research of influence of the corpuscular agent of solar activity on the human organism. Fundamental'nye issledovaniya, 2012, no. 11 (part 3), pp. 715-721 (in Russian).

22. Vashchenko V.I., Vil'yaninov V.N., Pavlova E.A., Sorokoletova E.F., Lesnichii V.V., Vashchenko T.N., Gusev S.V., Titulova T.B. Indices of hemostatic system and differential blood counts in blood donors upon changes in annual solar activity and its random perturbances. Vestnik gematologii, 2013, vol. 9, no. 2, pp. 70-74 (in Russian).

23. Laboratory of X-Ray Astronomy of the Sun, LPI. Available at: www.tesis.lebedev.ru (02.08.2021).

24. Piruzyan L.A., Chibrikin V.M. Geomagnetic stochastic control of vital activity. Doklady. Biochemistry and biophysics, 2006, vol. 410, no. 1, pp. 267-269. DOI: 10.1134/S1607672906050048

25. Krylov V.V. Biological effects of geomagnetic activity: observations, experiments and possible mechanisms. Trudy Instituta biologii vnutrennikh vod RAN, 2018, vol. 87, no. 84, pp. 7-38. DOI: 10.24411/0320-3557-2018-10016 (in Russian).

26. Unger S. The Impact of Space Weather on Human Health. Biomed. J. Sci. \& Tech. Res., 2019, vol. 22, no. 1, pp. 16442-16443. DOI: 10.26717/BJSTR.2019.22.003709

27. Bazhenov A.A., Prikop M.V., Averina A.S., Sukhovskaya V.V., Ukhova A.V. Response of biological systems to geomagnetic storms. Acta Biomedica Scientifica, 2018, vol. 3, no. 5, pp. 126-131. DOI: 10.29413/ABS.2018-3.5.18 (in Russian).

28. Leff J.A., Oppegard M.A., Curiel T.J., Brown K.S., Schooley R.T., Repine J.E. Progressive increases in serum catalase activity in advancing human immunodeficiency virus infection. Free Radic. Biol. Med., 1992, vol. 13, no. 2, pp. 143-149. DOI: 10.1016/0891-5849(92)90076-S

29. Rahal A., Kumar A., Singh V., Yadav B., Tiwari R., Chakraborty S. Dhama K. Oxidative stress, prooxidants, and antioxidants: the interplay. Biomed. Res. Int., 2014, no. 7, pp. 612-664. DOI: $10.1155 / 2014 / 761264$

Irkaeva A.M., Zhukova E.S., Shcherbatyuk T.G., Chernov V.V., Polyakova L.V., Pozdnyakova M.A., Umnyagina I.A. Geomagnetic changes as a risk factor causing oxidative stress in human erythrocytes. Health Risk Analysis, 2021, no. 3, pp. 134-140. DOI: 10.21668/health.risk/2021.3.13.eng

Received: 10.08 .2021

Accepted: 17.08 .2021

Published: 30.09.2021 